\title{
Social Inequality and the Rise of Localism in Hong Kong
}

\author{
STEPHEN ROBERT NAGY*
}

\begin{abstract}
An increasing number of people define themselves as Hong Kong citizens or as Chinese Hong Kong citizens, rather than as Chinese citizens. This shift in identity accompanies growing social inequality, revealed by Hong Kong's Gini Coefficient increasing from 0.525 in 2001 to 0.537 in 2011. Rising social inequality has led to localism/local-based nationalism. Is there a relationship between social inequality and increased localism? This paper argues that the growth of social inequality and increased localism in Hong Kong is partially related to migration schemes employed there to attract highly skilled global talent. This calls attention to increasing intra-ethnic distinction and discrimination in Hong Kong and its relationship to growing social inequality and localism.
\end{abstract}

Keywords: Hong Kong, Highly Skilled Migrants, Social Inequality, Nationalism, Localism

* Associate Professor, International Christian University (ICU), Tokyo, Japan; E-mail: nagy@icu.ac.jp

DOI: $10.16934 /$ isr.16.2.201512.25 


\section{INTRODUCTION}

The Gini Coefficient (GC) is a barometer for income disparity published by the Census and Statistics Department (C\&SD) in Hong Kong. The GC of Hong Kong was found to be 0.537 in December 2011, an increase from the GC of 0.525 in 2001 (Government of the Hong Kong Special Administrative Region [HKSAR] 2012 , 1) (see Figure 1). In concert with growing social inequality, we are also seeing a growth of nationalism as localism, a strengthening of the Hong Kong identity (Ma 2007, 150). According a survey conducted by the Public Opinion Programme at the University of Hong Kong (2012a), an increased number of Hong Kong people define themselves as Hong Kong citizens or Chinese Hong Kong citizens rather than Chinese citizens (see Figure 2). Is there a relationship between social inequality and increased localism? What are some of the driving forces behind these trends?

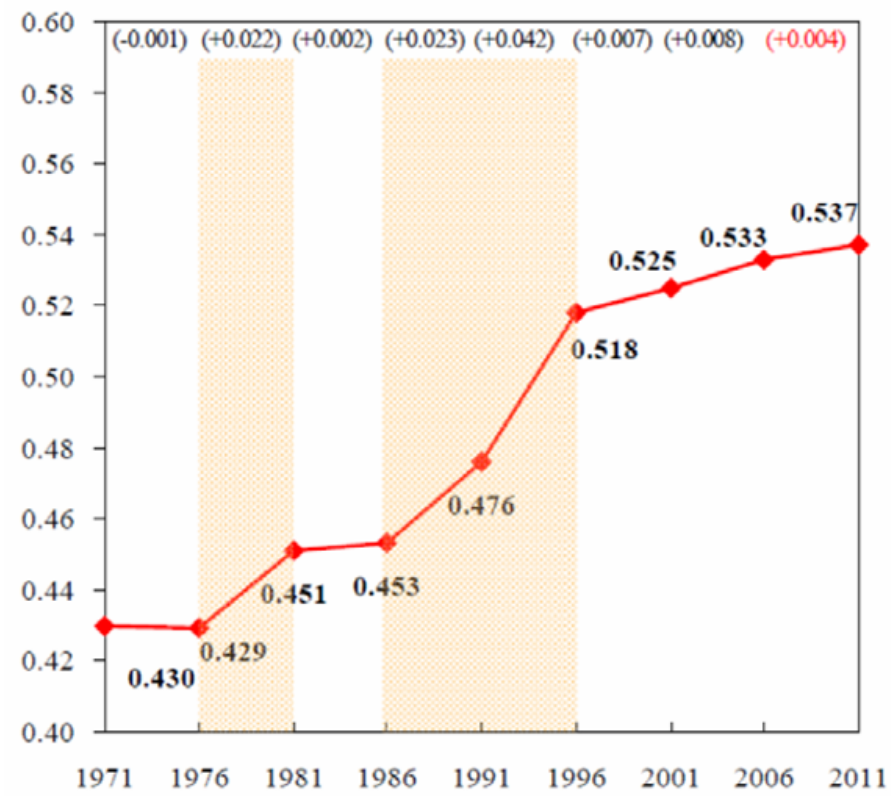

Figure 1. Gini COEFFICIENT BASED ON ORIGINAL HouseHOLD INCOME (GOVERNMENT OF HKSAR 2012, 1)

At the global scale, many scholars have highlighted the link between growing social inequality and the influx of highly skilled professionals and investors. Sassen $(2001,5)$ in her book The Global City stresses that cities are sites for (1) "the production of specialized services needed by complex organizations for running specialized services needed by complex organizations for running a spatially dispersed network of factories, offices, and service outlets; and (2) the 


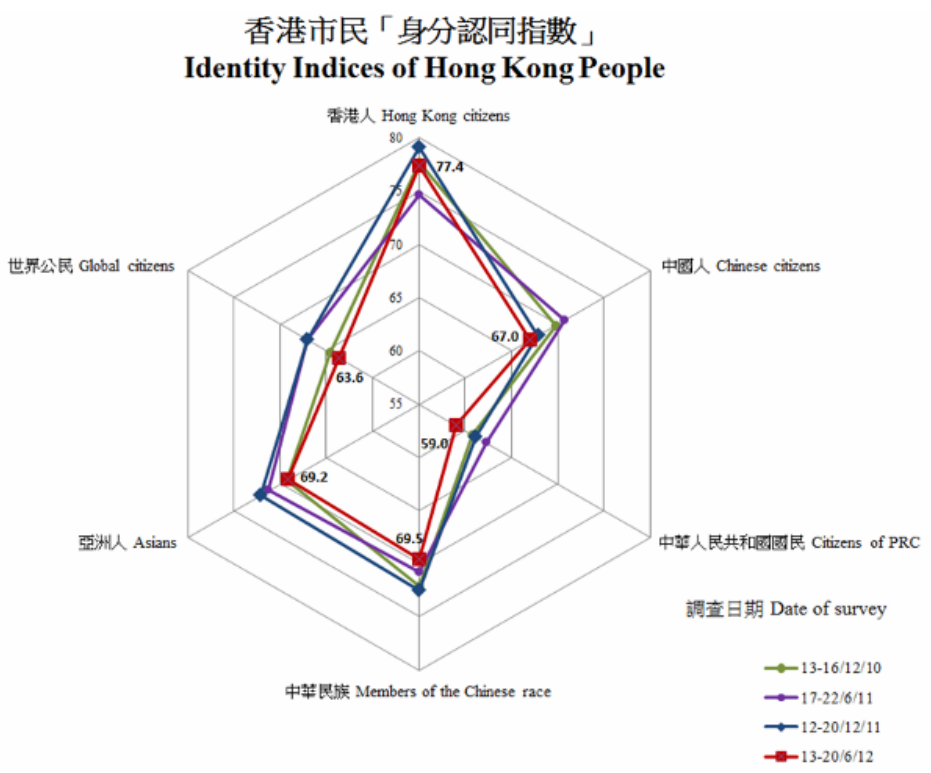

Figure 2. Identity Indices of Hong Kong People (Public Opinion PROGRAMME, 2012b)

production of financial innovations and the making of markets, both central to the internationalization and the expansion of the finance industry." This echoes Friedmann's (1986) World City hypothesis in that global cities become nodal points for the coordination of processes. Together, Sassen (1984) and Friedman (1986, 73) argue that with the emergence of global cities, we see a bifurcation of the city labor market with a large number of investors and professionals "specialized in control functions and, on the other, a vast army of low-skilled workers engaged in manufacturing, personal services and the hotel, tourist and entertainment industries that cater to the privileged classes for whose sake the world city primarily exists." In city states such as Hong Kong, the so-called highly skilled professional class and investors are often emigrants from Mainland China. They generally have inadequate working experience and skills that generate growing social inequality between the highly skilled/investor migrant upper class and the low-skilled roving underclass (Chui et al. 2013, 3; Tai 2006, 1752). This resonates with the study by Sassen (1984) on employment restructuring in New York City in which she argues that the emergence of global cities has increased polarization, reduced the number of middle-income careers and placed limitations on upward social mobility for non-skilled (Friedmann 1986, 79).

The growth in social inequality in Hong Kong has been attributed to many factors. For instance, grassroots organizations such as the Hong Kong Democratic Foundation (2007) argue that the growth in social inequality is linked to a troika of 
factors: increased mobility for global talent; Hong Kong's pro-talent immigration policies; and Hong Kong's geographic proximity to cheap labor in Mainland China. This proximity allows low skilled jobs to be transferred to Mainland China and leaves low-skilled workers remaining in Hong Kong with little employment opportunities.

Grassroots organizations try to contextualize the growth in social inequality in terms of globalization, migration and structural disadvantages to the low skilled in Hong Kong associated with the geographic proximity to China's cheap labor. However, the report on "Income Inequality in Hong Kong" produced by the Hong Kong Statistical Society stresses that the rise in inequality can be explained in at least six ways: (1) the migration of factories from Hong Kong to Mainland China, resulting in a large labor surplus; (2) the tendency for those of lower educational levels to be unemployed or underemployed; (3) an aging population; (4) emigrants from Mainland China with inadequate working experience and skills; (5) low taxation and the passive role of government in the economy; (5) property speculation; and (6) monopolization (Chui et al. 2013, 3). These conclusions are echoed by Tai (2006, 1752), who demonstrated that one of the main factors of social inequality in Hong Kong, Singapore and Taipei is the relationship between migration policy and the transformation of social structure.

Severino (1997, iv), Former Vice President of the World Bank East Asia and the Pacific, also pointed out that the inequality trend is driven by globalization and technological change favoring highly skilled individuals. Wojtyniak et al. (2010) also studied the impact of immigration of highly-skilled or low-skilled labor on wage inequality with a global perspective, using a specific-factors model. While many governments change their social and economic policies to attract global talent to sustain their prosperity, there are a number of challenges ahead. For example, the Singaporean policy of welcoming talent pits meritocracy against nationalism, as citizens began to question their national and cultural identity, and why foreigners receive support, and whether it is still worthwhile to be a local citizen (Ng 2011, 266; Amaldas 2009, 991-992). With this "brain gain" policy, Singapore has to integrate highly skilled foreign talent and their children into its multiethnic and increasingly cosmopolitan society, resulting in a more diverse culture and social inequality for governmental management (Mukhopadhaya 2003; Ng 2011, 267; Pang 2006, 162).

Others have drawn connections to the rise of social inequality and localism in Hong Kong to the policies aimed at boosting the Hong Kong economy after the 2003 SARS epidemic (Romann 2012; Tsoi 2012). In the wake of the SARS epidemic, the central government in Beijing attempted to provide a severely disrupted Hong Kong economy with much needed economic aid by lifting previous restrictions on the movement of services and population between the mainland and Hong Kong (Yep 2012). Employing the Closer Economic Partnership Arrangement 
(CEPA), Hong Kong saw a significant growth in the integration between Mainland China and Hong Kong, providing a substantive lift to the local economy. With the economic boost, Hong Kong saw a rapid increase in the number of Mainland professionals and importantly investors coming to invest in Hong Kong, and an increase in the number of Mainland tourists and property investors (Tsoi 2012). Accompanying this flow of capital, services and people there was an acceleration of social inequality in Hong Kong as newcomers to the city participated in the property market (Tsoi 2012; Drew 2012).

This paper argues that the growth of social inequality and nationalism (localism) in Hong Kong is partly related to the migration schemes for investors and highly skilled workers currently being employed in Hong Kong to attract global talent. This calls attention to the increasing intra-ethnic distinction and discrimination in Hong Kong and its relationship to growing social inequality and localism. In terms of methodological framework, this paper employs data from the Hong Kong Immigration Bureau, published in both English and Chinese. This data includes qualitative information on the kinds of migration policies that exist and quantitative data, including comparative figures on the number of highly skilled migrants settling in Hong Kong (temporarily or permanently), the sectors they work in and their relative income levels. This paper also includes policy papers on social inequality published by the Hong Kong government, the Hong Kong Democratic Foundation, the Hong Kong Statistical Society, and scholarly papers.

Primary data is drawn from unstructured interviews with 30 local Hong Kong citizens, 30 highly skilled migrants and Hong Kong Immigration Bureau staff in November and December of 2012. These interviews were conducted through network sampling. The voices of Hong Kong citizens, defined as having permanent residence in Hong Kong and a Hong Kong identity, were included to provide insights into how local citizens with Hong Kong identities view investors, highly skilled migrants and their links to growing inequality and nationalism. In contrast to this local perspective, interviews with investors and highly skilled migrants were included to incorporate the views and motivations of highly skilled migrants. Their perspective is important, as the country of origin of investors and highly skilled migrants plays a part in their interpretation of the link between growing social inequality and nationalism (localism)

\section{MIGRANT POLICIES FOR THE HIGHLY SKILLED}

Countries around the world and within the region have been active in formulating migrant policies for the highly skilled. For example studies by Oishi (2012) discuss the more proactive yet unsuccessful strategies used to attract highly skilled migrants to Japan. With the legal barriers removed or lowered, Oishi found that the hurdles that highly skilled migrants face in Japan include language and 
cultural demands of Japanese corporations, and a lack of financial assistance for families and their children for international schools. Other factors which attributed to the low attractiveness of Japan include lack of multicultural educational, challenges of career development, inflexible labor markets, gender inequality and work-life balance.

Research conducted on Singapore reflects Singapore's pragmatism when it comes to incorporating highly skilled migrants and investors to be leveraged for national prosperity while attempting to decrease their dependency ratios (Prime Minister's Office Singapore 2011; Leow 2010). While successful in incorporating highly skilled and non-skilled migrants, Singapore's migration policies have contributed to growing social inequality (Mukhopadhaya 2003, 55) and concerns over the affordability of housing for ordinary Singaporeans (Phang 2007). Simultaneously, Singapore's retention rate of highly skilled migrants continues to struggle with turnover as highly-skilled migrants see Singapore as a "fine" place to live and work in the short term. It is viewed as a much less attractive place in the long term owing to the size of the country, increasing property prices and an authoritarian government (Ministry of Manpower 2011, 24).

Canada and Australia continue to be beacons for highly skilled migrants. Their transparent migration schemes, affordable housing, high quality of education, multicultural settings and potential for residency and or citizenship remain attractive features for highly skilled migrants (Hawthorne 2011; Ontario Canada 2012).

The work permit scheme and points system in the UK effectively attract more temporary skilled migrants while limiting the social, cultural and economic impact of migration (Findlay 2006, 83; Shachar 2006, 192-193). Countries like the US have leveraged their education systems to encourage foreign students in their universities to stay on after graduation and to secure long-term jobs by visa extension, but this change also raised concerns about unemployment among local American job seekers (FoxNews.com 2011).

The plethora of strategies employed by the abbreviated list of countries above to attract investors and highly skilled migrants reflects recognition, on the part of policy makers, of the salient role of migrants in economic dynamism of a country, region or city. Strategies may differ depending on the region and cultural setting, but what is evident is that there is increased competition for investors and highly skilled migrants around the world.

\section{Hong Kong Migration Schemes}

According to the Hong Kong Special Administrative Region (HKSAR) Government (2012), 4,524,015 out of 7,103,700 Hong Kong residents held HKSAR passports in 2011. Most of the remaining non-HKSAR passport holders hailed from Mainland China followed by Indonesia $(133,377)$ and the Philippines $(133,018)$ 
(Census and Statistics Department, HKSAR [C\&SD] 2012, 18). These migrants include Migrant Domestic Workers (MDWs), day laborers, construction workers and migrants working in various types of services industries.

Although we saw a drop in the overall foreign population since 1996, since its return to the People's Republic of China (PRC) in June of 1997, Hong Kong has been able to remain autonomous vis-à-vis its immigration system under the "One-country, two systems" mantra. Part-in-parcel of this autonomy and based on the Basic Law, the HKSAR has exclusive control of entry and departure from Hong Kong of nationals from around the world, in addition to control over the entry of passport holders from Mainland China. This includes issuing travel documents, visas, identity cards as well as registering births, deaths and marriages.

The HKSAR Immigration Bureau's comprehensive functional role suggests its central role in maintaining Hong Kong's population changes while simultaneously ensuring that this global city remains attractive to investors, skilled and non-skilled migrants. The rationale for this is threefold. First, Hong Kong's role as a financial hub in Asia is dependent on having a flexible migration policy that allows high skilled professionals to quickly insert themselves into the local economy and immediately begin producing results. Second, the growth of China and especially competing financial centers such as Shanghai requires Hong Kong to adopt competitive policies that facilitate and attract professionals, investors and highly skilled workers. Third, to maximize its geographic, cultural and historical location between China and the West, Hong Kong has prioritized the transition from a manufacturing and export/import based economy to one that revolves around the financial sector and the services sector/knowledge economy. This priority requires an immigration policy that can insert globally competitive workers into the Hong Kong economy with minimal bureaucratic red tape.

To accomplish these objectives, the HKSAR Immigration Bureau uses a "Quality Migrant Admission Scheme" (QMAS), "Capital Investment Entrant Scheme" (CIES), an "Entry for Employment as Professionals" scheme (EEPS) and an "Employment of Non-Local Students" scheme (ENLS). The QMAS aims to attract the best and brightest talent to fill prominent roles as professionals, artists and athletes. The CIES stresses attracting investors that would help vitalize the local economy and contribute to Hong Kong's overall regional and global competiveness. The third scheme maintains a liberal stance when it comes to professionals and those individuals adding value to Hong Kong. This includes any individual that will add value to the HKSAR through their experience, skill, education or investments. Lastly, the ENLS strives to keep talented and employable individuals that have been trained in Hong Kong as it strives to enhance the overall human capital of the SAR.

This system is complemented by a flexible migrant domestic worker (MDW) program, which permits large numbers of MDW to enter Hong Kong work as domestic workers. Why is this program such a germane component of Hong 
Kong's immigration package? The reason is that it resonates with overall objectives of Hong Kong's goal of creating an economically dynamic, inclusive, global city. Domestic workers were and are crucial players in the Hong Kong economy for several reasons: (1) They allow Hong Kong women to participate in the work force; (2) they fill the void in child care services which exists in Hong Kong; and (3) the preference for English speaking MDW who function as a helper and English language assistant (Oishi 2005, 25). Without MDWs, one family member, most likely the woman, would need to stay home from work to take care of children. The effect of this is that an individual is removed from contributing to the economy, less household income is accrued, and less income tax can be collected by the government. This income is especially important when we consider average rental costs in Hong Kong which places larger and larger burdens on renters as well as potential property owners.

Lastly, it should be mentioned that the HKSAR has strict guidelines in terms of how many Mainland Chinese can settle in Hong Kong. Settlement does not refer to study, investment, or travel with the appropriate documents. According to the HKSAR Immigration Bureau, in 2009 around 49,000 Mainlanders joined their families in Hong Kong under the One-way Permit Scheme (daily quota: 150) (HKSAR Information Services Department 2010, 412). As argued by Shipper $(2010,14)$, differentiated citizenship confers different positions, interests and rights for Hong Kong residents and PRC residents, despite most sharing a formal citizenship with the PRC. This differentiated citizenship and the associated economic benefits pulls Mainland migrants to Hong Kong, creating a need for an immigration policy that controls the flow of Mainland migrants into Hong Kong.

It is clear that the HKSAR immigration policy is formulated to maintain economic vibrancy by several means. First, it enables men and women to work in Hong Kong and contribute to its global vision. Second, it fills the vacuum in social welfare services that exists with inexpensive MDWs. Third, it creates transparent migration streams that allow for investors, professionals, skilled and non-skilled workers to enter Hong Kong and immediately contribute to its economic productivity. Fourth, the existing system attempts to address the differentiated citizenship that exists between Hong Kong and the Mainland by creating opportunities for investors, students and specialists from the Mainland to enter legally while at the same time it ensures that Hong Kong is not overrun with migrants from the Mainland.

These objectives are firmly grounded in strong and evolving principles that protect skilled and non-skilled workers. In the case of skilled workers such as professionals, they may only take up a job that cannot be performed by a local worker. This policy ensures that the local workforce is maximized while simultaneously this policy guarantees that overseas professionals are joining legitimate organizations. Non-local students, on the other hand, including those graduates 
from Hong Kong universities, have up to one-year to find a job before they are required to leave the region. They are further protected from wage discrimination based on their nationality or citizenship through wage protection in that they can only take up a position in Hong Kong remunerated at market rates (HKSAR Information Services Department 2010, 132). This protection creates an employment culture that remunerates employees based on education and ability rather than citizenship or nationality status. It also facilitates integration of non-local graduates into Hong Kong through equal protection under the law.

In the case of so-called non-skilled workers like MDWs, the HKSAR government has attempted to ensure a constant flow of MDWs into Hong Kong by putting forth transparent, contractual and flexible policies specifically targeting, while at the same time protecting MDWs. For example, in principle the Hong Kong government will only admit experienced MDWs. Moreover, potential employers must offer employment as stipulated in the standard employment contract prescribed by the government (HKSAR Information Services Department 2010, 132). This includes free and "suitable accommodation," free meals or a meal allowance, wages not lower than minimum wage, free passage to home country and free medical treatment. Notwithstanding the guarantees that MDWs enjoy, MDWs remain in tenuous situations with their employers and there are many cases of abuse, neglect and employers not fulfilling their contracts (Oishi 2005, 24).

Moreover, despite well known cases of abuse, Hong Kong continues to remain a Mecca for MDWs in the region for both pull and push reasons. Transparent contracts, as well as an established MDW community, transnational advocacy groups, wages and demand from the Hong Kong side act as considerable incentive pulling MDWs in the region to join the 240,000 plus domestic workers found in Hong Kong (Hsia 2009). Continued discrepancies in economic development, lack of employment opportunities and the need to support families on the other hand, push MDWs to Hong Kong seeking ways to escape their economic and social woes in their home countries.

\section{Growth of Inequality and Nationalism (Localism): Highly Skilled Migrants vs.}

\section{Low-skilled Migrants}

The facilitation of investors and highly skilled migrants by the above Hong Kong migration schemes has been important in bolstering Hong Kong's position as one of the premier destinations for the highly skilled migrant. With its low taxes, migrant domestic worker scheme, plethora of choices of school options for children, Hong Kong offers the highly skilled migrant many incentives to settle semi-permanently or permanently. As of 2012, 38,820 of non-local talents and professionals were approved for employment in Hong Kong under various employment-based policies (C\&SD 2011, 35). In 2007, some 33,000 highly skilled migrant population 
were approved for employment in Hong Kong, mainly from the Mainland (18\%), US (11\%), UK (9\%), Japan (7\%) and Australia (6\%) (See Table 1) (Legislative Council Commission 2008, Annex B). Around 40\% of them were engaged in administrative and managerial work, and the rest were mostly professionals and technicians in different sectors (Legislative Council Commission 2008, 2).

Table 1. Nationality/Place of Origin of Approved Applicants (LeGislative COUNCIL COMMISSION, 2008, ANNEX B)

\begin{tabular}{lrrrrr}
\hline $\begin{array}{c}\text { Nationality/ } \\
\text { Place of Origin }\end{array}$ & $\mathbf{2 0 0 3}$ & $\mathbf{2 0 0 4}$ & $\mathbf{2 0 0 5}$ & $\mathbf{2 0 0 6}$ & $\mathbf{2 0 0 7}$ \\
\hline Mainland & 1,350 & 3,745 & 4,029 & 5,031 & 6,075 \\
US & 2,041 & 2,524 & 2,981 & 2,846 & 3,473 \\
UK & 2,201 & 2,626 & 2,543 & 2,779 & 3,055 \\
Japan & 2,286 & 2,255 & 2,096 & 2,090 & 2,140 \\
Australia & 1,434 & 1,599 & 1,819 & 1,745 & 2,121 \\
India & 642 & 994 & 1,188 & 1,403 & 1,948 \\
Taiwan & 677 & 821 & 1,013 & 1,274 & 1,499 \\
Philippines & 597 & 837 & 1,125 & 856 & 1,083 \\
Canada & 619 & 701 & 912 & 840 & 927 \\
Singapore & 474 & 725 & 778 & 962 & 975 \\
Others & 5,008 & 6,337 & 6,899 & 7,509 & 9,600 \\
$\quad$ Total & $\mathbf{1 7 , 3 2 9}$ & $\mathbf{2 3 , 1 6 4}$ & $\mathbf{2 5 , 3 8 3}$ & $\mathbf{2 7 , 3 3 5}$ & $\mathbf{3 2 , 8 9 6}$ \\
\hline
\end{tabular}

There does not seem to be a direct correlation between the rise of localism and social inequality and the influx of investors and highly skilled migrants until the 1997 handover. Before the handover, Hong Kong's Immigration Department estimated the skilled migrant population in 1983 at 150,000 persons of whom 19,600 were British. By December 1992, however, the majority of overseas expatriates came from many advanced industrial nations, for example 23,500 from USA, 16,000 from the UK and 12,300 from Japan with an overall figure of 283,300 and a sharp increase amongst low-wage immigrant groups such as Filipinos (Findlay et al. 1996, 51). Tight migration rules specified how many migrants could come from the Mainland, and the aforementioned migration scheme did not exist. With reunification came changes in Hong Kong's migration scheme to attract highly skilled migrants from the Mainland as well as attract their investments into the Hong Kong economy (Wang 2012, 568-569). As mentioned previously, the Closer Economic Partnership Arrangement (CEPA) initiated in the aftermath of the SARS epidemic in 2003 was also a contributing factor to the increased influx of Mainland migrants and large sums of investment.

With the introduction of the various migration schemes set forth by the Hong Kong Immigration Bureau, we saw growing numbers of highly skilled and low/ un-skilled Mainland migrants and investors coming to Hong Kong. The highly skilled migrants worked in professional services such as finance and banking while the low and unskilled took up positions in the blue-collar and peripheral economy. 
Investors from the Mainland, on the other hand, under the 'Capital Investment Entrant Scheme' (CIES) received residency permits through the large investments

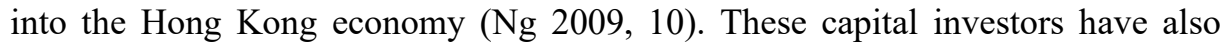
been prominent investors in the Hong Kong property market and it is these investments that have been attributed to growing social inequality in Hong Kong.

In discussions with informants concerning the links between investors (and to a lesser degree highly skilled migrants), social inequality, and the rise of localism, there seemed to be consensus that the increase in social inequality and localism was linked to migration. More specifically, my informants placed a significant amount of blame for growing social inequality on the highly skilled and investor migrants from the Mainland rather than highly skilled migrants in general. For instance, the following local Hong Kong bank employee, a high school teacher and a fireman voiced the following opinions when asked about the relationship between growing social inequality and migration:

Highly skilled migrants from the West generally move back to their homelands or to another country so they don't really contribute to rising rent price. In many cases, it's their companies that rent their apartments and they are not part of the buyers' market. The Mainland migrants on the other hand, especially the rich ones come to Hong Kong and purchase property as an investment. Sometimes they don't even live in the flats they buy, they just wait until the prices go up and then sell it for a profit. Their property purchases are increasing the cost of a flat month by month making it increasingly difficult for locals (Hong Kong citizens) to buy a flat. I wish the government would do something about it but they just think about money and not about ordinary citizens (Hong Kong bank employee, interview, December 2012).

My wife and I cannot afford the initial down payment on a flat. The Mainlanders keep pushing flat prices up high and higher. Even with the levy, non-permanent residents must pay when they buy a flat in Hong Kong, they still have the money to easily buy a flat. I always wonder how they got so rich with such little education (local high school teacher, interview December 2012).

Westerners are not the problem when it comes to the increasing costs of living in Hong Kong. They usually live in places that are already too expensive for local Hong Kong people like the Peak, Mid-Levels and Repulse Bay. I think the increased cost of living and growing inequality is because of bad government policy, especially allowing Mainlanders to so easily come to Hong Kong and buy property. They are driving rent and property prices sky high making it impossible for young people to get enough money together to buy even a small apartment in Kowloon (retired fireman, interview, November 2012). 
The above voices on the impact of highly skilled migrants in Hong Kong highlight several points. First, they make the connection between growing social inequality and investor migrants from the Mainland rather than highly skilled migrants in general. Second, they understand that the Hong Kong government's migration scheme to facilitate Mainland migrants coming to Hong Kong as professsionals or investors is in part responsible for the growing inequality. Third, each of the voices above clearly draws an intra-ethnic distinction between Hong Kong citizens and Mainlanders. This distinction between Mainlanders and Hong Kong citizens is evidence of a growth of localism (strengthening of the Hong Kong identity) as a byproduct of growing social inequality associated with Mainland migrants into Hong Kong. Fourth, and linked to the idea of growing localism, the informants interviewed also introduced us to growing intra-ethnic discrimination connected to growing numbers of migrants from the Mainland.

\section{Highly Skilled Migrants and Social Inequality}

The interviews suggest that the intra-ethnic discrimination targeted at Mainland migrants was not uniform. At one level, intra-ethnic discrimination is targeted at wealthy Mainlanders who are associated with increased social inequality in Hong Kong because of their purchase of properties within Hong Kong (Tsoi 2012; Oriental Daily 2012; VOA 2013). When asked "how do migrants from China contribute to inequality?" interviewees mentioned the below:

Ever since 1997 we have seen more and more rich Mainland migrants come to Hong Kong to buy property and secure a Hong Kong ID. I guess they see it as a kind of insurance policy for their money in China. The problem is that many buy apartments as investments and they are driving property prices higher and higher. Our wages cannot keep up with the increased cost of housing and the influx of Mainland buyers is not slowing down (female graduate student, interview, November 2012).

For these Mainland migrants, Hong Kong's Basic Law makes Hong Kong an incredibly safe location to invest wealth accrued in Mainland China (VOA 2013). It has also been noted that investment in the Hong Kong property market functions in other capacities as well. These include securing a Hong Kong Permanent Resident Identification Card, a legal way to launder illegally derived funds in the Mainland, (VOA 2013) and residency permission, access to Hong Kong's social welfare system, schools, and ease of travel (Tsoi 2012; Oriental Daily 2012).

\section{Low-skilled Migrants and Cultural Friction}

For "native" Hong Kong residents, these investor Mainland migrants are 
directly responsible for local inflation, sky rocketing property prices and a growing inequality between those who can and cannot access property.

At the second level, intra-ethnic discrimination against Mainland migrants is targeted at the low-income Mainland migrants and Mainland mothers who give birth in Hong Kong. These migrants are seen in an unflattering light in at least two ways. First, are seen as migrants who are exploiting Hong Kong's relatively generous social welfare net (Chu 2012; Tsoi 2012; Oriental Daily 2012). Disgruntled locals commonly talk about Mainland migrants as being net takers of the social welfare benefits in Hong Kong, regularly citing how they fill public housing, school seats for local children and hospital beds (Oriental Daily 2012). When asked "What is the source of friction between Hong Kong citizens and Mainland migrants?" some interviewees voiced the following views:

Mainland migrants, especially those with no education come to Hong Kong expecting everything for free. They try to get public housing, subsidies for education and other benefits without paying their fair share. Many don't even try to learn Cantonese or Hong Kong culture! (Office worker, interview December 2012)

In a connected issue, Hong Kong locals see Mainland mothers who come to Hong Kong to give birth as being one of the major reasons for the shortage in hospital beds for local women who need to give birth (Chu 2012; Tsoi 2012). For example, the following new Hong Kong mother shared her birthing experience.

It was difficult to find a bed to give birth to in the hospital. There are just so many Mainland mothers coming to Hong Kong to give birth that us locals find it difficult for the hospital of our choosing to take us. The Mainland women give birth here to get a permanent resident card for their child (new Hong Kong mother, interview, November 2012).

As social inequality increases in relation to increased migration from the Mainland under Hong Kong migration schemes, we are seeing growing anti-Mainland sentiments in various sectors of Hong Kong society and a growing sense of animosity towards Mainlanders in general. This rise in localism, or local nationalism, has resulted in several prominent issues between local Hong Kong citizens and their Mainland co-ethnics coming to life including the problem of cross-border births, the manners of Mainland migrants and tourists in Hong Kong, the powder milk shortage, and parallel trading (Tsoi 2012; Oriental Daily 2012).

According to the Hong Kong Government in 2010, there were 88,000 births in Hong Kong, 45\% which were from Mainland mothers (Mong 2012). In 2011, the public outcry against Mainland mothers giving births in Hong Kong public 
hospitals has resulted in the Hong Kong Health Authority implemented a quota of 3,400 (from 10,000) which limits the number of births of non-local women in public hospitals in Hong Kong. Similarly, private clinics have also been limited to 31,000 births by non-local women (Mong 2012).

Another example occurred in January 2012 when a Mainland child was filmed eating on the train in Hong Kong. Her actions were seen as an example of Mainlanders not following Hong Kong rules and importantly a syndrome of Mainland migrants coming to Hong Kong but not following the local customs including learning Cantonese (Apple Daily 2012; Minter 2012). One of my informants stressed the problem in the following way:

Mainland migrants, especially the ones from the rural areas have no idea about how to live in big cities and about Hong Kong ways of living and behaving in public. They smoke and eat everywhere, they don't pick up their rubbish and they seem to not try to adapt to our local ways (Hong Kong small business owner, interview, December 2012).

A more recent example of the Mainland migrant-Hong Kong tension has to do with the so-called parallel traders who have been deemed responsible for the shortage of baby infant milk powder in Hong Kong. These parallel traders purchase milk powder in Hong Kong where products are highly regulated and transport them across the border back to Mainland China for profit (Wong and Chan 2013). The end result of the parallel trading is that local Hong Kong citizens point at Mainland migrants as the primary reason for shortages in milk powder (owing to parallel trading) (Wong and Chan 2013).

Each example above demonstrates a growing sense of distinction between Mainland and Hong Kong people. Although not directly related to highly skilled migrants, the above tensions are a by-product of local frustration over growing social inequality associated with Mainland migrants, especially the highly skilled migrants polarizing Hong Kong's economic landscape through investment, property and specialization that reinforces hurdles or creates higher hurdles for social mobility from the Hong Kong middle class.

With that in mind, one is immediately faced with the question of why are Mainland migrants the scapegoat for growing social inequality. Why not blame all migrants instead of just Mainland migrants? Is there an ideological side to this intra-ethnic discrimination or something related to China's economic growth and its impact on Hong Kong? Is this growth in intra-ethnic discrimination, rise in inequality and rise in localism (nationalism) somehow related to Hong Kong's highly skilled migration policies or a result of Hong Kong's migration policy in general? The following section will attempt to answer some of these questions. 


\section{DISCUSSION}

The growth of highly skilled migrants into Hong Kong has grown hand-inhand with Hong Kong's transformation into one of the financial hubs in East Asia and the world. Its colonial past has given it the accruements to create a financial architecture based on rule of law, transparent governance and sound institutions. Its proximity to the Mainland and comparatively high level of development compared to China transformed Hong Kong into the gateway to investment and trade in China. Hong Kong's Basic Law provides foreign firms security, predictability and a platform for expansion into the Chinese market. These features make Hong Kong an attractive location for the regional head offices of many businesses doing business in China. Simultaneously, as the number of regional headquarters increase in Hong Kong with the specific purpose of doing business in China so does the need for highly skilled migrants with the linguistic, cultural and professional skills necessary to negotiate and ultimately succeed in the Chines market (China Economic Review 2010)

By in large, the individuals with these skills hail from or have deep experience with the Mainland and thus we should expect a further Mainlandization of the highly skilled professional migrant class in Hong Kong. If this is the case, then we should predict that social inequality and localism should continue to deepen in Hong Kong as the economy continues to bifurcate into highly skilled professional classes, investors and non-skilled/skilled areas. My research has shown that local Hong Kong citizens recognize the connection between growing numbers of highly skilled migrants and social inequality. That being said, they also have developed an understanding of the different kinds of highly skilled migrants and migrants in general and their impact on Hong Kong society.

This research echoes the conclusions of Sassen (1991) and Friedmann (1986) in that the influx of highly skilled migrants into cities has a polarizing effect and this polarization is apparent in Hong Kong as well. The growing social inequality that Hong Kong is experiencing and the growing divide between the highly skilled professional class and a less/unskilled lower class, who are largely confined to the peripheral of the economy with little or no room for social mobility, is an empirical demonstration of this polarization of the city. Moreover, informants in this research have revealed that the polarization that is occurring is mostly associated with migrants, both highly skilled and unskilled, from Mainland China. The link between Mainland migrants and growing social inequality has helped fuel growing localism, intra-ethnic distinction and discrimination. In this light, the Hong Kong government must be more prudent and develop migrant policies that prevent or reduce social inequality and the rise of localism, intra-ethnic distinction and discrimination. Simply increasing the criteria of the "Quality Migrant Admission Scheme" (QMAS), "Capital Investment Entrant Scheme" (CIES), an "Entry for Employment as Pro- 
fessionals" scheme (EEPS) and an "Employment of Non-Local Students" scheme (ENLS) will not decelerate the increase in social inequality and rise in localism. A multi-pronged policy approach that include highlighting the economic benefits of highly skilled migrants to the Hong Kong economy, preferred rent and purchasing plans for permanent and long term residents of Hong Kong and a long term strategy of human capital develop in Hong Kong are part of the solution.

Informants in this study have also provided insight as to the link between growing localism in Hong Kong, social inequality and migrants from the Mainland. Their views resonate with Wang $(2012,566)$ and the assertions of Schittenhelm and Schmidtke (2010) that "skilled migrants often experience the uneven and difficult processes of integration and marginalization, belonging and detachment in ways that are not clearly distinguished from the experiences of the non-skilled." It was clear from the voices of informants that both at the level of the highly skilled migrant and the low skilled migrant that local Hong Kong people struggled to find commonality and often constructed us versus the dichotomy in which Mainlanders were perceived as less educated, less civilized, less mannered and in some cases not entitled to the same benefits that Hong Kong citizens enjoy. This dichotomization contrasts with the positive images of highly skilled migrants as "global careerists" (Ho 2011), who move between cities and countries in a "frictionless world" (Willis et al. 2002, 505) and this study revealed that in fact there is friction and the highly skilled migrant's lifestyle may not be without issue. This was especially true of the migrants from the Mainland who is seen as one of the major causes behind social inequality.

The targeted intra-ethnic distinction and discrimination against Mainlanders and obfuscation of non-Mainland highly skilled migrants as contributors to growing social inequality uncloaks another germane aspect of the growth of localism in Hong Kong: an ideologically or politically-based bias against co-ethnics. This finding buttresses Wang's thesis that "mainland skilled immigrants in Hong Kong are deeply embedded in an overarching xin yimin (new immigrants) discourse according to which the Hong Kong-China border distinguishes all Mainland immigrants from Hong Kong citizens regardless of the level of skills they possess" (Wang 2012, 568).This distinction includes having different mother tongues and being born and raised in different political and socio-cultural systems.

This permanent bias against Mainland migrants may be in part related to Hong Kong's historical separation from the Mainland as a colony of Britain, its continued status as a Special Administrative Region and its historical high level of development compared to the Mainland. For many Hong Kong citizens, China remains a byword for corruption, poverty, communism, and backwardness, characteristics that are carried across bounders by Mainland migrants and encountered in intra-ethnic tensions that are represented in growing social inequality and intercultural friction. Policy development to alleviate the growth in social inequality 
associated with highly skilled Mainland migrants will need to take these biases into consideration, as a stand-alone migration policy that does not include acculturation policies for new migrants and the host community will only strengthen current biases.

The intra-ethnic discrimination/distinction, growing social inequality and strengthening localism which is intensifying in Hong Kong present a serious policy challenge for the Hong Kong's policy makers. At the identity level, policy makers must develop a migration scheme that attempts to maintain Hong Kong's identity in light of increased numbers of Mainland migrants settling in Hong Kong permanently or semi-permanently. This will become increasingly difficult as numbers of highly skilled Mainland migrants increase and the natural incentives to assimilate or integrate that befell low-skilled migrants become irrelevant (Nagel 2005).

Overcoming this challenge is not without difficulty. The adoption of something akin to the Dutch Newcomers Act of 1998 (Ministry of the Interior and Kingdom Relations Directorate for the Coordination of Integration Policy for Minorities 2002; Goodman 2010) with its Dutch as a second language (NT2) requirement, Social Orientation (MO) and Vocational Orientation courses that conclude with a test may be a disincentive to highly skilled migrants. The Dutch approach with its post twelve-month in-country test on social orientation may further decrease the attractiveness of Hong Kong as an attractive destination for highly skilled migrants from around the world and from the Mainland.

The Canadian approach of stressing legal, government, and social welfare access through one of the two official languages while letting incoming cultures naturally find their equilibrium within Canada's multicultural societal fabric does not address the problems associated with growing social in equality and intra-ethnic discrimination (Kymlicka 2007, 106).

The recent multicultural coexistence approaches being implemented in Japanese communities to integrate all levels of migrants has also been heavily critiqued as merely a truncated form of integration that provides only superficial support for migrants (Nagy 2012, 491-493).

Singapore, perhaps Hong Kong's nearest example in terms of associated problems, with growing social inequality, has also not been able to find a way out of the polarization trap associated with migration policies centered on attracting highly skilled migrants (Mukhopadhaya 2003; Ng 2011; Pang 2006).

The current economic integration approach, in which investors and highly skilled migrants can easily make their way to Hong Kong, has brought enormous wealth to the city. Simultaneously, investors and to a lesser degree highly skilled migrants, have had a polarizing effect on the economy and on identity, in particular those migrants that come from the Mainland. In terms of social inequality and further polarization of the Hong Kong citizenry, policy makers are faced with the 
challenge of continuing to make Hong Kong an attractive destination for investors and highly skilled migrants while simultaneously preventing or diminishing current social inequality trends associated with highly skilled migrants. This Gordian knot is not easily untied as highly skilled migrants often form "asymmetrical power relationships" (Yeoh and Willis 2005, 271) with their host societies because of professional skills, financial resources and extension human capital and their associated networks. The highly skilled migrants in Hong Kong are no different in this capacity except that the migrants from the Mainland, with their educational, language and cultural capital, have a higher capacity to become settlers compared to their Western highly skilled migrant counterparts.

\section{MOVING FORWARD}

Hong Kong's growing social inequality and the trend of localism associated with highly skilled migrants is a social conundrum that policy makers to date have been ineffective at addressing. Hong Kong's economic dynamism is inextricably linked to the Mainland's growth and openness between the two neighbors has been deepened do to the Closer Economic Partnership Arrangement (CEPA). However, this economic proximity and dependency has opened the migrant Pandora's Box in that increased prosperity is linked to investors and highly skilled migrants that are in part responsible for growing inequality, social tension and localism. Hong Kong's over reliance on the finance industry and property as wealth generators are also important factors in limiting Hong Kong's policy makers from tackling this problem through a restructuring of the economy.

The way forward will necessarily include investing much more heavily in cultivating domestic/local human capital. Creating a locally training professional class with the skills to conduct business in China may alleviate some of the need for investors and highly skilled migrants from the Mainland. That being said, the cultivation of local talent will not be able to meet the needs of all sectors of the economy and as a result there will be some latent dependency on highly skilled migrants from abroad and in particular from Mainland China. If social inequality is not addressed through greater investment in local human capital development and programs that facilitate social mobility for the middle class, localism is bound to grow in cancerous ways fomenting further intra-ethnic discord.

Concurrently with any further investment in local human capital development, both the Hong Kong government and the Mainland government can contribute to fostering better intra-ethnic relations through cultural sensitivity programs, language programs and decreasing the necessity for Mainland highly skilled migrants to invest in Hong Kong property. The latter obviously requires increased transparency, attention to the rule of law and investment in the very features that make Hong Kong an attractive place for highly skilled migrants. 


\section{REFERENCES}

Amaldas, Marystella. 2009. The Management of Globalization in Singapore: Twentieth Century Lessons for the Early Decades of the New Century, Journal of Alternative Perspectives in the Social Science 1(3): 982-1002.

Apple Daily. 2012. Gangtie jinshi niang Zhonggang ma zhan 港鐵進食釀中港罵戰 [Mainlander Eating within Hong Kong MTR caused Controversy between Mainland and Hong Kong]. January 17. Retrieved 1 March 2013, http://hk.ap ple.nextmedia.com/news/art/20120117/15990832.

Census and Statistics Department (C\&SD). 2011. Hong Kong as a KnowledgeBased Economy: A Statistical Perspective (2011 edition). Hong Kong: Census and Statistics Department.

C\&SD. 2012. 2011 Population Census Thematic Report: Ethnic Minorities. Hong Kong: Census and Statistics Department.

China Economic Review. 2010. Cover Story: A Tale of Two Cities. China Offshore. Winter. Retrieved 1 March 2013, http:/www.chinaoffshore.net/content/taletwo-cities.

Chu, Kathy. 2012. Tensions Grow Over 'Mainlanders' Giving Birth in Hong Kong. USA Today. February 20. Retrieved 1 March 2013, http://usatoday30.usato day.com/news/world/story/2012-02-14/chinese-mainland-pregnant-womenhong-kong/53159886/1.

Chui, Lap., Shong Tong Leung, and Chun Hin Yip. 2012. Income Inequality in Hong Kong. Hong Kong Statistical Society. Retrieved 22 January 2013, http:/www.hkss.org.hk/SPC/2011-12/AwardPDF/S11-12-DP4.pdf.

Drew, Kevin. 2012. In Hong Kong, Frustration 15 Years after Return to Chinese Rule. New York Times. June 29. Retrieved 28 February 2013, http://www. nytimes.com/2012/06/30/world/asia/in-hong-kong-frustration-after-return-tochinese-rule.html? pagewanted=all\&_r=0.

Findlay, Allan Mackay. 2006. Brain Strain and Other Social Challenges Arising from the UK's Policy on Attracting Global Talents, in Christiane. Kuptsch and En Fong Pang (eds.), Competing for global talent. Geneva: International Institute for Labour Studies: International Labor Office; Singapore: Wee Kim Wee Centre, Singapore Management University.

Findlay, Allan Mackay, Alan John, Jowett, and Ronald Skeldon. 1996. Skilled International Migration and the Global City: A Study of Expatriates in Hong Kong, Transactions of the Institute of British Geographers New Series 21(1): 49-61.

FoxNews.com. 2011. Obama Administration Lets More Foreign Students Stay in the U.S. for Jobs, Raising Competition Concerns. May 17. Retrieved 28 February 2013, http://www.foxnews.com/politics/2011/05/17/dhs-allows-fo reign-students-extended-stay/. 
Friedmann, John. 1986. The World City Hypothesis, Development and Change 17(1): 69-83.

Goodman, Sara Wallace. 2010. Integration Requirements for Integration's Sake? Identifying, Categorising and Comparing Civic Integration Policies, Journal of Ethnic and Migration Studies 36(5): 753-772.

Government of Hong Kong Special Administrative Region (HKSAR). 2012. The Gini Coefficient of Hong Kong: Trends and Interpretations, in Half-yearly economic report 2012-special topics (Box 5.2, 1-4). Hong Kong: Government of HKSAR. Retrieved 27 February 2013, http:/www.hkeconomy.gov. hk/en/pdf/box-12q2-5-2.pdf.

Hawthorne, Lesleyanne. 2011. Competing for Skills: Migration Policies and Trends in New Zealand and Australia-Full Report. New Zealand: Department of Labour; Australia: Department of Immigration and Citizenship.

Ho, Elaine Lynne-Ea. 2011. Migration Trajectories of 'Highly Skilled' Middling Transnationals: Singaporean Transmigrants in London, Population, Space and Place 17(1): 116-129.

Hong Kong Democratic Foundation. 2007. Inequality in Hong Kong [policy paper]. Retrieved 31 January 2013, http://www.hkdf.org/pr.asp?func=show\&pr=169. HKSAR Government. 2012. Hong Kong: The Fact-Immigration. Retrieved 1 March 2013, http:/www.gov.hk/en/about/abouthk/factsheets/docs/immigrat ion.pdf.

HKSAR Information Services Department. 2010. Hong Kong Yearbook 2009. Hong Kong: Information Services Department.

Hsia, Hsiao Chua. 2009. The Making of a Transnational Grassroots Migrant Movement. Critical Asian Studies 41(1): 113-141.

Kymlicka, Will. 2007. Multicultural Odysseys: Navigating the New International Politics of Diversity. Oxford: Oxford University Press.

Legislative Council Commission. 2008. Administration's Paper on Admission Arrangements for Employment of Talent and Professionals. Panel on Security, LC Paper No. CB(2)347/08-09(05). December 2. Retrieved, March $1^{\text {st }}$, 2012, http://www.legco.gov.hk/yr08-09/english/panels/se/papers/se1202cb2347-5-e.pdf.

Leow, Hui Min Annabeth Carolynn Rebecca. 2010. Singaporeans' Perceptions of Pronatalism, Foreign Talent Policy and Connections in Population Policy. September 13-18. Paper presented at the $6^{\text {th }}$ International Students Science Fair 2010: Investigating Science and Social Responsibility-A World Class Forum for the World's Best Youth Scientific Minds, Australian Science and Mathematics School, South Australia.

Ma, Eric. 2007. Grassroots Nationalism: Changing Identity in a Changing Context. China Review 7(2): 149-167.

Ministry of Manpower. 2011. Relocation Practices: For Incoming Global Talent 
to Singapore. Singapore: Ministry of Manpower, International Manpower Division.

Ministry of the Interior and Kingdom Relations Directorate for the Coordination of Integration Policy for Minorities. 2002. Integration of Newcomers Acts (WIN). Retrieved 1 March 2013, http://www.degeschiedenisvaninburgering. nl/docs/win/factsheets-engels3-02.pdf.

Minter, Adam. 2012. Tension Boils over Spilled Noodles in China, Bloomberg. January 25. Retrieved 1 March 2013, http://www.bloomberg.com/news/201201-25/tension-boils-over-spilled-noodles-in-china-adam-minter.html.

Mong, Adrienne. 2012. Birth Rights Battle: China vs. Hong Kong, NBC News. February 13. Retrieved 1 March 2013, http://behindthewall.nbcnews.com/ _news/2012/02/13/10394026-birth-rights-battle-china-vs-hong-kong?lite.

Mukhopadhaya, Pundarik 2003. Trends in Income Disparity and Equality Enhancing Education Policies in the Development Stages of Singapore, International Journal of Educational Development 23: 37-56.

Nagel, Caroline. 2005. Skilled Migration in Global Cities from 'Other' Perspectives: British Arabs, Identity Politics, and Local Embeddedness, Geoforum 36(2): 197-210.

Nagy, Stephen Robert. 2012. Local Government Migrant Policies in Tokyo, Japan: National Exclusion, Local Inclusion. New York: Edwin Mellen Press.

$\mathrm{Ng}$, Michael . 2009. Relationship Between New Immigration Policies and Chinese Immigrants Characteristics: Evidences in Hong Kong. Paper presented at the First Annual Conference on Development Studies, the Graduate Institute of Development Studies, National Chengchi University, Taiwan. November 2829. Retrieved 1 March 2013, http://ics.nccu.edu.tw/ced/admin/data/PANELB/B6.1.pdf.

Ng, Pak Tee. 2011. Singapore's Response to the Global War for Talent: Politics and Education, International Journal of Educational Development 31(3): 262-268.

Oishi, Nana. 2005. Women in Motion: Globalization, State Policies, and Labor Migration in Asia. California: Stanford University Press.

Oishi, Nana. 2012. The Limits of Immigration Policies: The Challenges of Highly Skilled Migration in Japan, American Behavioral Scientist 56(8): 1080-1100. Ontario Canada. 2012. Applying for Permanent Residence. Retrieved 28 October 12. February 2013, http://www.sse.gov.on.ca/medt/investinontario/en/Pages/ bi_corp_services_perm_residence.aspx.

Oriental Daily. 2012. Zhonggang ronghe fuzuoyong, dangduanbuduan bi shengluan 中港融合副作用 當斷不斷必生亂 [The side effect of Hong Kong-Mainland Integration, the government who hesitate is lost]. January 12 . Retrieved 1 March 2013, http://orientaldaily.on.cc/cnt/news/20120112/00186_001.html. Pang, Eng Fong. 2006. Foreign Talent and Development in Singapore, in Christiane. 
Kuptsch and Eng Fong Pang (eds.), Competing for global talent. Geneva: International Institute for Labour Studies: International Labor Office; Singapore: Wee Kim Wee Centre, Singapore Management University.

Phang, Sock-Yong. 2007. The Singapore Model of Housing and the Welfare State, Research Collection School of Economics (OpenAccess) Paper 596. Retrieved 28 February 2013, http://ink.library.smu.edu.sg/soe_research/596.

Prime Minister's Office Singapore. 2011. Prime Minister Lee Hsien Loong's National Day rally 2011 (speech in English), Sunday, 14 August 2011 at University Cultural Centre, National University of Singapore. Retrieved 28 February 2013, http://www.pmo.gov.sg/content/pmosite/mediacentre/speech esninterviews/primeminister/2011/August/Prime_Minister_Lee_Hsien_Loon gs_National_Day_Rally_2011_Speech_in_English.html.

Public Opinion Programme, The University of Hong Kong. 2012a. HKU POP Releases Latest Survey on Hong Kong People's Ethnic Identity [press release]. December 27. Retrieved 27 February 2013, http://hkupop.hku.hk/english/po pexpress/ethnic/eidentity/poll/chart/eIdentity_hkcitizen.gif.

Public Opinion Programme, The University of Hong Kong. 2012b. Identity Indices of Hong Kong People. Retrieved 27 February 2013, http://hkupop.hku.hk/ english/release/chart_20120626_big.gif.

Romann, Alfred. 2012. HK Faces Challenge of Redefining Itself. China Daily Hong Kong Edition, H2. October 12.

Sassen, Saskia. 1984. Capital Mobility and Labor Migration: Their Expression in Core Cities, in M. Timberlake (ed.), Urbanization in the World Economy. New York: Academic Press.

Sassen, Saskia. 2001. The Global City: New York, London, Tokyo (2nd edition). Princeton, NJ: Princeton University Press.

Schittenhelm, Karin and Oliver Schmidtke. 2010. Integrating Highly Skilled Migrants into the Economy: Transatlantic Perspectives. Paper presented at the $17^{\text {th }}$ CES Biennial Conference, Montreal. April 14-17. Retrieved 1 March 2013, http://www.newschool.edu/tcds/wr10reader_citizenship/4_Schmidtke_ Schittenhelm_Highly-Skilled\%20Migrants.pdf.

Severino, Jean Michael. 1997. Foreword, in Vinod Ahuja, Benu. Bidani, Francisco Ferreira, and Michael Walton (eds.), Everyone's Miracle? Revisiting Poverty and Inequality in East Asia. Washington, D.C.: World Bank.

Shachar, Ayelet. 2006. The Race for Talent: Highly Skilled Migrants and Competitive Immigration Regimes. New York University Law Review 81: 148206.

Shipper, Apichai. 2010. Politics of Citizenship and Transnational Gendered Migration in East and South East Asia. Pacific Affairs 83(1): 11-30.

Tai, Po-Fen. 2006. Social Polarisation: Comparing Singapore, Hong Kong and Taipei. Urban Studies 43(10): 1737-1756. 
Tsoi, Grace. 2012. Integration Anxiety, Asia City Online. February 16. Retrieved 28 February 2013. http://hk.asia-city.com/city-living/article/integration-anxiety.

VOA. 2013. Gangren nanzhiye Daluren beizhi tuigao Xianggang wujia 港人難置 業 大陸人被指推高香港屋價 [Hong Kong people are difficult to buy property. Mainland buyers were blamed for pushing flat prices up high]. February 28. Retrieved 1 March 2013, http://www.voacantonese.com/content/mainland ers-blamed-for-keeping-hk-properties-out-of-reach-20121004/1520 205.html.

Wang, Cangbai. 2012. Bridging Borders in the Global City: Negotiating Sameness and Difference in Hong Kong's Skilled Immigrants from Mainland China. Journal of International Migration and Integration, 13(4), 565-581.

Willis, Katie, Brenda Yeoh, and S.M. Abdul Khader Fakhri. 2002. Transnational Elites, Geoforum 33(4): 505-507.

Wong, Wei-chen. S. and Wei-Heng Chan. 2013. Haiwo naifen wangmin Wangjiao wei Neidike jihua Zhonggang maodun 還我奶粉 網民旺角圍內地客 激化 中港矛盾 [Return milk powder to me! Netizen besieged Mainlanders in Mong Kok, aggravating Mainland-Hong Kong conflicts], Sky Post. January 28. Retrieved 1 March 2013, http://www.skypost.hk/\%E6\%B8\%AF\%E8\%81 $\% 9 \mathrm{E} / \% \mathrm{E} 8 \% \mathrm{~A} 6 \% 81 \% \mathrm{E} 8 \% 81 \% 9 \mathrm{E} / 20130128 / 001 / \% \mathrm{E} 9 \% 82 \% 84 \% \mathrm{E} 6 \% 88 \% 9$ $1 \%$ E5\%A5\%B6\%Е7\%B2\%89/72433.

Wojtyniak, Beata., Udo. Broll, and Sugata. Marjit. 2010. Low and Highly Skilled Labor Immigration and Wage Inequality, Technology and Investment 1: 97100.

Yeoh, Brenda and Katie Willis. 2005. Singaporean and British Transmigrants in China and the Cultural Politics of 'Contact Zone,' Journal of Ethnic and Migration Studies 31(2): 269-285.

Yep, Ray. 2012. Hong Kong-Mainland Tension on the Brink of Explosion, Brookings Northeast Asia Commentary 62. October. Retrieved 28 February 2013, http://www.brookings.edu/research/opinions/2012/10/09-hong-kong-yep. 